\title{
Extraverted consciousness, introverted consciousness, and composition of lyrical discourse
}

Keywords: extraverted consciousness; introverted consciousness; lyric poetry; composition; foregrounding; backgrounding

Słowa klucze: świadomość ekstrawertyczna; świadomość introwertyczna; liryka; kompozycja; pierwszy plan dyskursu; drugi plan dyskursu

\section{Extraverted and introverted consciousness}

In his (1994) book W. Chafe draws extremely important distinction between extraverted and introverted consciousness. The former one is involved when we report our immediate experience, the latter in the case of remembering, imagination, evaluation, theoretical thinking, etc.

The crucial contrast between these two modes of thinking, and, of course, between two respective types of language, is that in the case of extraversion relevant situation is perceived as a part of the flow of events, as, so to speak, contextualized, while introverted thinking is de-contextualized, as it were, insular. In other words, the extraverted mode suggests infiniteness, openendedness of our experience, while the introverted one island-like nature of every event.

As far as in a certain intuitively clear sense introverted consciousness is far and away poorer, when describing past events speakers normally look for 
some compensatory devices. One of them is historical present, i.e. the mode of telling the story as if suggesting immediate involvement of the author. Another tool widely used here is setting events in a concrete spatial and/or temporal location, which, as it were, hints at the possibility of further elaboration of our notion of these events; that is why so many stories open with adverbials of space and/or time.

Note that in most cases an event can be remembered, imagined, evaluated, subsumed under some wider category of events, etc. without mental specification of its setting, hence in general locative and temporal adverbials are more strongly associated with extraverted mode of thinking.

According to (Chafe 1994), the above distinction may be crucial for the structure of both literary narrative and texts we produce in our everyday communication. What I claim here is that the same distinction, if in a substantially different way, plays a role in compositional organization of lyrical poems.

In the first place, I must make some important points on how lyrical discourse is generally constructed.

\section{Foregrounding and backgrounding in lyrical discourse}

It is well known that our cognition follows the principle of hierarchization: e.g., the meaning of a word normally comprises assertion and presupposition, as well as some other kinds of information, among which assertion is in some sense or other the most important; another example is the ranking of thematic roles in the (morpho)syntactic structure of the sentence, where the subject in many respects takes precedence over the direct object, and the latter takes precedence over obliques, etc.

The same is true of the discourse as a whole, where foregrounded and backgrounded parts are normally detectable, with possible further subtler subdivisions within the foreground and background.

In the works of P. Hopper and S. Thompson (see (Hopper, Thompson 1980), in the first place) and their followers (see, e.g., (Hopper, Thompson 1982); see also the extremely influential book (Fleischman 1990)) it was established that various languages develop a comparable set of means serving to distinguish between the main plot ( = foreground) and the less important additional information (such as descriptions, comments, evaluations, digressions, etc. 
$=$ background) in narrative text. For instance, perfective, telic, punctive, and transitive verbs are typical of the foreground here, while for the background imperfective, atelic, non-punctive, intransitive verbs are more common. More recently, L. Talmy (2010) has moved beyond morphosyntactically realized strategies for foregrounding/backgrounding and has noted a number of lexical semantic strategies by which languages indicate the information that is attentionally prioritized in sentences and longer texts.

While narration is the best studied type of discourse, it is beyond doubt that some mechanisms of grounding are at work in other types of discourse as well, inter alia in lyrical poetry. On the other hand, it is obvious that both the concrete purposes of grounding in lyrical poems, and its specific linguistic markers may be different from those in narrative.

It is usually claimed that the foregrounded parts of lyric poem are those where metaphor, metonymy, hyperbole, oxymoron or other figure of speech is present and/or where some deviation from a linguistic (semantic, syntactic, pragmatic, stylistic) or literary norm occurs; see in the first place the works of G. Leech, e.g. (1969); such recent works as (Shen 2007; Nofal 2011; Manin 2012) show how persistent is this view.

In my opinion, this contention is only partially accurate, for at least two reasons.

First, in many cases such an analysis is counterintuitive, since in fact figurative speech and deviations can be present in what naïve reader perceives as more and less important parts of the lyric poem.

Second, if limiting analyses of lyrical texts to the above claim, scholars risk overlooking a more fundamental structural division that was described as early as in 1977 by the Russian literary scholar Tamara Sil'man (1977). She noted that, by its nature, lyrical discourse tends to comprise two clearly distinct and opposed parts. On the one hand, the lyric poem must present some experience in which the author is involved. On the other hand, this experience should lead the author to some conclusion, to comprehension of some truth and/or to a change in her mental/emotional attitude towards the world. This split between the aspects of lyrical literature and its contribution to the aesthetic properties of the literatures has also been recently developed by Wallace Chafe (2013), who has noted the importance of experience and transcendence in creating what native speakers understand to be a beautiful and deeply true aspect of literary production and experience. 
Evidently, it is the 'comprehension', which is more important and, in some sense or other, foregrounded in lyric discourse.

While this bipartition directly follows from the genre specificity of lyric poetry, and hence is primary to the structuring of lyrical discourse, to the best of my knowledge, it has never been studied in detail by linguists. The first thing to be done here is detection and classification of most typical linguistic means recruited to signal the distinction, and this issue will be, if in a small way, addressed below.

In principle, any reasonably salient dissimilarity between two parts of the text can suggest that they are not equal in terms of grounding. Imagine, for instance, a poem where the background is marked by absence of adjectives, while in the foreground they are abundant, or a poem where the background is very low, and the foreground is extremely high in agentivity (such poems are indeed to be found!). However, examination of about 500 lyric poems written in Russian, Polish, English, Spanish, Portuguese, and Japanese has shown that there is a relatively small set of most typical, recurrent linguistic devices employed for the task.

Thus, the 'comprehension' part of the poem (which I will call focus for short) is often linked to its experiential part with greater number of discourse relations than any fragments of the latter one are linked to one another. To take another example, in quite a few instances the focus is marked by a referential break, i.e. by absence of expected referential links with other (experiential) fragments; see for details (Зельдович 2015; Zeldowicz 2015).

\section{Proposal}

Returning now to the distinction between extraverted and introverted consciousness, the hypothesis immediately suggests itself that since the focus tends to be more general, more abstract in meaning than the experiential part of the poem, and hence tends not to be in need of any 'contextualization', it will display a much clearer tendency towards being a piece of introverted thinking.

Let it be also noted that while in the empirical part of the poem the author is normally the subject of some experience, and hence a concrete person (no matter whether real or fictitious), the generalization we find in focus is in many cases product of depersonalized conscience. Therefore, this (hypothetical) 
regularity must be due not only to the contrast between the content of what is said in experiential and focal fragments, but also to the disparity of the crucial cognitive and communicative attitudes of the subject of speech, i.e. those attitudes, which in some intuitively clear sense are even prior to the relevant speech acts.

Of course, here it is impossible to test the above claim on a larger scale, which is left as a task for future research. Nonetheless, I hope to present some evidence supporting it in a very clear and uncontroversial way.

Let it be recalled that, according to (Chafe 1994), adverbials of space and time are typical of extraverted mode of thinking, and are rare and marked in introverted language.

The first assumption coming to mind here is that such adverbials must be more numerous in experiential fragments and palpably less so in focal ones. It may well be that this assumption holds true, but I did not check it against my material for the simple reason that a much more interesting, more specific and at the same time more 'exquisite' assumption also supporting my basic claim was born out.

This assumption consisted in that it is the border between the empirical and the focal parts of the poem which tends to be marked by the presence/ absence of adverbials with locative or temporal semantics. To be more precise, the assumption was this.

Suppose that some stanza of a lyric poem contains two predications or two chains of predications such that (a) first come(s) predication or a chain of predications, which contain(s) locative and/or temporal adverbial(s); (b) next come(s) predication or a chain of predications, where no such an adverbial is to be found. My claim is, if this condition is satisfied, it is highly probable that the former predication(s) belong(s) to the empirical part of the poem, while the latter one(s) to its focus.

In other words, since a predication with locative/temporal adverbials is more likely to be the product of extraverted consciousness, and a predication without such adverbs has better chances to arise from introversion, the transition from the former to the latter may well be used as a marker of experiencecomprehension distinction in lyrical discourse. 


\section{Material}

In order to verify the above hypothesis, I examined 50 Russian lyrical poems belonging to as famous poets as A. Puškin, M. Lermontov, F. Tiutčev, M. Cvetaeva, O. Mandelštam, B. Pasternak, A. Tarkovsky.

When analyzing material, I adopted the following important conventions.

First, what I understood by term 'predication' was either a simple sentence (no matter whether independent or constituting a part of a complex one), or secondary predication, as exemplified by trying in I will die trying.

Second, as mentioned earlier, not every transition from predications with space and/or time adverbials to predications without such adverbials was taken into account, but only such a transition occurring within the limits of one stanza. Apart from keeping things simple, this convention is justified by the fact that each stanza, at least in the prototypical case, constitutes a saliently distinct and integral unity, hence the shift in the mode of conceiving the world will be felt here more strongly, and, of course, has better chances for being compositionally significant.

Third, as I also said above, such a transition was taken into account, only if the opposite change is not to be found later in the same stanza, i.e. there is no transition from predication(s) lacking locative and temporal adverbials to predication(s) in which such adverbials appear. The motivation behind this restriction is quite simple: if it is true that the shift from predications where spatial and/or temporal parameters are explicitly specified to predications lacking such indication makes it more probable that the latter ones are introversion-oriented, and thus belong to the focus of lyrical discourse, then the reverse transition would neutralize this effect, and considering relevant examples in our counts could obfuscate the regularities we are trying to discover.

Fourth, as is well known, in complex sentences subordinate clause can indicate place or time, and display behavior with respect to the main clause more or less comparable to that of ordinary locative and temporal adverbials. However, intuitively such clauses are still not locative/temporal adverbials, and for this reason, as well as because of extreme paucity of relevant material and for the sake of simplicity, they were not taken into account. On the other hand, conjunctions with locative and temporal meaning, such as, e.g., where or when, apart from serving the function of connecting two parts 
of the sentence, additionally play the role of ordinary adverbials of, respectively, place and time within relevant subordinate clause. Thus, such subordinate sentences as When you come... in When you come, I will be happy were treated as 'adverbialized' in the above defined sense.

The texts under analysis were divided into four types.

Type 1. The relevant poem contains a fragment, such that (a) it belongs wholly to one stanza; (b) one or several predications present in it involve(s) adverbials of place and/or time; (c) one or several following predication(s) do(es) not; (d) the former predication(s) belong(s) to the experiential part of the poem, while the latter to its focus.

Quite obviously, this is the type of examples lending immediate support to my main claim.

Let it be noted that this type was also taken to cover several poems, where, apart from the focus itself, properties (a-c) were additionally found at the very beginning of the text. The reason is that the initial stanza of lyrical poem is practically never foregrounded, it is practically never becomes the point where the most significant truth is discovered; hence if some features generally characteristic of focus is to be found here, their presence must be explained by special communicative and aesthetic goals totally alien to the issue at hand.

As an example, consider the famous poem «Парус» ("The Sail") written by Y.M. Lermontov:

1 .

Белеет парус одинокой

В тумане моря голубом. -

Что́ ищет он в стране далекой?

Что́ кинул он в краю родном?

A white lonely sail is seen

In the blue mist of the sea. -

What is it (lit. he) looking for in the far land,

What has it (lit. he) left in its (lit. his) native land?

2.

Играют волны, ветер свищет, И мачта гнется и скрыпит; 


\footnotetext{
Увы! - он счастия не ищет

И не от счастия бежит! -

Waves are playing, wind whistling,

And the mast is bending and creaking;

Alas! - it (lit. he) does not look for happiness

And does not escape from happiness! -
}

3.

Под ним струя светлей лазури, Над ним луч солнца золотой: А он, мятежный, просит бури, Как будто в бурях есть покой! Below it (lit. him) there is a flow clearer than azure, Above it (lit. him) there is a golden beam of Sun:But it (lit. he), rebellious, asks for a storm, As if in storms there were calmness!

In the first stanza, every of the three predications contains an adverbial of place ((в тумане моря голубом 'in the blue mist of the sea', в стране далекой 'in the far land', в краю родном 'in its (his) native land'), so that here there is no contrast of the type which we are interested with. Such a contrast is also absent from the second stanza, for the simple reason that no relevant adverbial is to be found here. However, in the third one the initial and the second predications comprise locative adverbials (под ним 'below it (him)', над ним 'above it (him)'), while the following predication is lacking such an adverbial: the expression в бурях 'in storms' might look as indication of place, but in fact its primarily locative meaning is metaphorized here to such a degree that on closer inspection its treatment as an adverbial of place proves to be totally counter-natural.

Thus, within the limits of the concluding stanza, two predications with explicit markers of place are followed by predication lacking such a marker. At the same time, it is evident that this predication encompassing the last two lines is the poem's most significant discovery and its compositional focus. Thus, here the shift from the language, which explicitly signals spatial orientation, to the language lacking such indications coincides with the border between the experiential part of the poem and its focal, foregrounded fragment. 
Type 2. The relevant poem contains at least one fragment, such that (a) it belongs wholly to one stanza; (b) one or several predications present in it involve(s) adverbials of place and/or time; (c) one or several following predication(s) do(es) not; (d) both the former and the latter predication(s) belong(s) either to the experiential part of the poem, or to its focus.

What we find here are counter-examples to our basic hypothesis, since in this case the transition in question does not occur at the point where the experiential part of the poem ends and its focus begins, and hence it cannot serve as a focus marker.

For the reasons explained several paragraphs earlier, I did not classify with this type those poems where the transition I am concerned with was found only in the initial lines of the text: once they practically never happen to be the focus, such a transition can be neither evidence, nor counter-evidence to my claim.

To illustrate, let us look at another famous poem of Y.M. Lermontov:

1.

Выхожу один я на дорогу;

Сквозь туман кремнистый путь блестит.

Ночь тиха. Пустыня внемлет Богу,

И звезда с звездою говорит.

Alone, I come out to the road;

The stony path is shining through the mist.

The night is silent. The desert is listening to God,

And one star speaks with another star.

2.

В небесах торжественно и чудно!

Спит земля в сиянье голубом...

Что же мне так больно и так трудно?

Жду ль чего? Жалею ли о чём?

In the Heaven, it is solemn and miraculous!

The earth is sleeping in blue glitter...

So why I feel such a pain and such hardness?

Do I wait for anything? Do I lament anything?

3.

Уж не жду от жизни ничего я,

И не жаль мне прошлого ничуть. 
Я ищу свободы и покоя!

Я б хотел забыться и заснуть!

I do not expect anything from life,

And I do not lament the past in the least.

I am looking for freedom and peace!

I would like to forget myself and fall asleep!

4.

Но не тем холодным сном могилы...

Я б желал навеки так заснуть,

Чтоб в груди дремали жизни силы,

Чтоб, дыша, вздымалась тихо грудь,

But not with that cold sleep of the grave...

I would like to fall asleep forever in such a way

That my vital force would sleep lightly in my breast,

That, breathing, my breast would raise silently,

\section{5.}

Чтоб, всю ночь, весь день мой слух лелея,

Про любовь мне сладкий голос пел,

Надо мной чтоб, вечно зеленея,

Темный дуб склонялся и шумел.

In such a way that, cherishing my ears for all the night, [and] all the day,

A sweet voice would sing for me about love,

Above me, being eternally green,

A dark oak would lean and rustle.

In the first stanza, both the first and second predications, Выхожу один $я$ на дорогу 'alone, I come out to the road' and Сквозь туман кремнистый nуть блестит 'the stony path is shining through the mist', contain adverbials of place, while in the following three predications, Ночь тиха 'the night is silent', Пустыня внемлет Богу 'the desert is listening to God', [3]везда с звездою говорит 'one star speaks with another star', neither locative, nor temporal adverbial appears. Once again, here a shift occurs from explicit speaking of space to the lack of such speaking, but the main discovery of this poem is evidently made not in the first stanza (stanza 5 is most certainly focal here), hence this shift is not in the least indicative of the transition from experience to generalization. 
Stanzas 2 and 4 are quite similar to the first one in this respect. In stanza 2, its first predication contains the locative adverbial в небесах 'in the Heaven', but the following four predications fail to specify location or time in explicit manner. In stanza 4, the predication comprised in line 2 contains the temporal adverbial навеки 'forever', and the predication comprised in line 3 contains the indication of place в груди 'in my breast', while the last line does not say anything explicit about either place or time.

Thus, the shift from explicit 'spatialization'/'temporalization' to the lack thereof can be observed in stanzas 1,2 and 4. Still, neither of them sounds as the focus of this poem; intuitively, the focus is constituted by the last stanza, where the shift in question does not occur.

Type 3. The relevant poem contains a fragment, such that (a) it belongs wholly to one stanza; (b) one or several predications present in it involve(s) adverbials of place and/or time; (c) one or several following predication(s) do(es) not; (d) the former predication(s) belong(s) to the experiential part of the poem, while the latter to its focus, and the same poem contains also at least one fragment, such that (a) it belongs wholly to one stanza; (b) one or several predications present in it involve(s) adverbials of place and/or time; (c) one or several following predication(s) do(es) not; (d) both the former and the latter predication(s) belong(s) either to the experiential part of the poem, or to its focus.

Obviously, here we face a contamination of types 1 and 2, i.e. the case where in one and the same poem there is both evidence supporting our claim, and counter-evidence to it. It may well be that in some examples the relevant evidence is weaker, than counter-evidence, since only one 'transitional' fragment can mark the border between the empirical and focal parts of the text, but several of them could in principle be detected at its other points. However, in my material all of the poems belonging to this type contained only one piece of such a counter-evidence, hence these examples are in fact neutral with respect to the hypothesis under discussion.

Such is, for instance, the following poem by A.S. Puškin:

1.

Храни меня, мой талисман,

Храни меня во дни гоненья, 
Во дни раскаянья, волненья:

Ты в день печали был мне дан.

Keep me safe, my lucky charm,

Keep me safe in the days of persecution,

In the days of repentance, excitement:

You were given to me on the day of sadness.

2.

Когда подымет океан

Вокруг меня валы ревучи,

Когда грозою грянут тучи, -

Храни меня, мой талисман.

When the ocean will raise

Around me its roaring waves,

When clouds will burst with storm, -

Keep me safe, my lucky charm.

3.

В уединеньи чуждых стран, На лоне скучного покоя, В тревоге пламенного боя Храни меня, мой талисман. In the solitude of foreign lands, On the bosom of dull calm, In the agitation of fervent battle Keep me safe, my lucky charm.

4.

Священный сладостный обман, Души волшебное светило...

Оно сокрылось, изменило...

Храни меня, мой талисман.

The sacred sweet deceit, The miraculous sun of my soul, It disappeared, betrayed...

Keep me safe, my lucky charm.

5.

Пускай же ввек сердечных ран

Не растравит воспоминанье. 
Прощай, надежда; спи, желанье.

Храни меня, мой талисман.

Let remembrance never embitter

The wounds in my heart.

Farewell, hope; sleep, desire.

Keep me safe, my lucky charm.

In stanza 2, in its two initial predications, Когда подымет океан Вокруг меня валь ревучи 'when the ocean will raise around me its roaring waves' and Когда грозою грянут тучи 'when clouds will burst with storm' the conjunction когда 'when' plays the additional role of adverbial of time, while in the last predication of this stanza, Храни меня, мой талисман 'keep me safe, my lucky charm', there is no adverbial of either time or place. (It should be noted that, according to one of the above adopted conventions, a whole subordinate clause indicating place or time is not treated as locative/temporal adverbial with respect to its main clause, but conjunctions of the type of when are assumed to be adverbials modifying the relevant subordinate clause).

In stanza 5, first a construction with temporal adverbial ввек 'never' appears (lines 1-2), and next come three predications without any adverbial whatever (lines 3-4).

However, stanza 2 does not belong to the focus of this poem, but stanza 5 does, hence the transition in question does not serve here as marker of composition.

Type 4. There is no transition of the above described kind anywhere in the text. Evidently, such examples are also irrelevant for the matter at hand. ${ }^{1}$

To illustrate, let us take a brief look at the poem of G.V. Ivanov:

${ }^{1}$ As far as this type is defined in a negative way, many subtypes are possible here. One of them was already mentioned: sometimes within the limits of one stanza first proposition(s) with adverbial(s) of place/time appear(s), then proposition(s) without such adverbial(s) come(s), and then again proposition(s) with explicit locative/temporal modifiers show(s) up. Another quite obvious possibility is that at the beginning of stanza we find proposition(s) without such adverbials, and next, at its end, proposition(s) 'adverbialized' in the above defined way. 
1.

Здесь в лесах даже розы цветут, Даже пальмы растут - вот умора! Но как странно - во Франции, тут, Я нигде не встречал мухомора. Here in forests even roses blossom, Even palm trees grow - that's hilarious!

But it is strange that here, in France, I never found a toadstool!

2.

Может быть, просто климат не тот -

Мало сосен, березок, болотца...

Ну, а может быть, он не растет, Потому что ему не растется Maybe, the climate is just different Few pines, birches, some bogs...

Or, maybe, it does not grow

Because it just does not feel like growing

3.

С той поры, с той далекой поры -

...Чахлый ельник, Балтийское море,

Тишина, пустота, комары,

Чья-то кровь на кривом мухоморе...

Since that time, that distant time -

...Sickly fir grove, the Baltic sea,

Silence, emptiness, mosquitos,

Someone's blood on a writhen toadstool...

It is immediately clear that here there is not a single instance, where within the confines of the same stanza the shift occurs from predications containing adverbials of space and/or time to those lacking such adverbials. Thus, this example is totally irrelevant for the verification of my basic hypothesis.

\section{Results and discussion}

Let it be reminded that the analysis of my material was undertaken in order to verify two interrelated claims. 
The first, quite general hypothesis is that the focus of lyrical poem tends to be a product of introverted consciousness, and, of course, must display some reasonably clear signs of it.

The second assumption was as follows. Since adverbials of place and time are more natural in extraverted language, their demonstrative, as it were, specially underscored absence can suggest that the relevant part of the text is produced by introverted consciousness. Therefore, it is reasonable to think that in lyrical poems such an absence would be symptomatic of focus. To keep things simple, I narrowed down a bit the scope of this claim, and hypothesized, more specifically, that if within the limits of the same stanza of a lyric poem some predication(s) containing adverbial(s) of place and/or time precede(s) (an)other predication(s) lacking such an adverbial and being the last predication(s) in the relevant stanza, it is highly probable that the border between the former one(s) and the latter one(s) coincides with the point where the empirical part of the poem is over, and its focus begins.

The analysis of 50 poems I conducted discovered a storytelling difference in the incidence of each type of examples. On the one hand, I found 10 texts belonging to Type 3, and 19 texts belonging to Type 4, i.e. to the types, which are irrelevant for verification of the above assumption. On the other hand, there were only 6 examples of Type 2, i.e. examples contradicting it, and as many as 15 examples of Type 1 lending it support. That is to say, the shift from predication(s), which mark(s) spatial and/or locative orientation in explicit way to predication(s), where no such marking obtains, is 2,5 times more probable at the border between empirical fragments and the focus than at any other point of lyrical poem, and hence such a shift can be viewed as marker of its foregrounded part.

Thus, my second claim was fully confirmed. This, of course, is also indicative of the truthfulness of my first, more abstract claim: introverted thinking is more typical of the focal, foregrounded part of lyrical discourse.

True enough, in the light of the above presented counts, what we find here is not a one-to-one correspondence between introverted mode of thinking and focus, but this is not a surprising or discouraging result. As my work in progress suggests, among many typical features of focus (to which belong, e.g., richness of discourse relations linking it to other parts of the text, its relative referential isolation from the rest of the text, higher incidence of discourse new entities in focus, etc.; see for details Zeldowicz 2015; Зельдович 
2015; Zeldowicz forthcoming), there is not a single one indicating its privileged discourse status unequivocally. Rather, several different properties tend to conspire to mark the foreground of lyrical text, hence both additional creativity of each single poem, and the lack of need for having any 'absolutely reliable' foregrounding device.

What is called for in future is an extensive study of other characteristic traits of extra- and introverted language and their employment as markers of experience-comprehension distinction in lyrical discourse.

For instance, if the focus of lyrical poem tends to be referentially dissociated from the rest of the text, this in some sense or other definitely impedes the flow of language, and thus might be also indicative of insularity, introverted orientation of the focus (recall that the lack of the need of context is very typical of introverted thinking).

To take another example, consider evidential markers, i.e. words and expressions indicating the source of relevant information, which can be obtained both through direct perception, in an extraverted way, or through introversion - mental calculation, imagination, etc.; see for details, e.g., (Яковлева 1994). It may well be that such markers tend to be distributed in lyrical text in a non-accidental manner, also serving to mark the above discussed crucial compositional division.

\section{Concluding remarks}

There is still one more, if tentative conclusion to be drawn from the discussion so far.

As early as in 1924 the famous Russian literary scholar and semiotician Jury Tynianov coined the notion of 'density of poetic range' (теснота стихового ряда, see Тынянов 1924/1965). Roughly speaking, the idea is that poetical language is distinguished by very high, unparalleled level of informativeness. What instantly comes to mind in connection with this proposal is that, at least in general, the focus of lyrical poem must be even more informative than its experiential part.

Of course, there is plenty of evidence pointing in this direction. As I said earlier, discourse new entities are more abundant in focus; my work in progress shows that linguistic information comprised in focus tends to be typologically more diversified; that metaphors found in focus tend to imply more 
fundamental revision of our initial knowledge of the world, and hence be more informative; that argumentative structure of focal fragments often presupposes revision of relevant default expectations, which also makes the sense of focus more 'concentrated', etc.

The results of my modest study presented above also support this view. Since extraverted thinking is 'flow-like', it presupposes a (principally infinite) context for every event, while introverted thinking, being 'island-like', treats every event as self-sufficient, treats it in a way practically excluding the need for any additional information. Thus, in some intuitively clear sense introverted language is more informative, more 'concentrated', which may well be another reason for its high incidence in foregrounded fragments of lyrical texts.

\section{Bibliography}

Chafe W., 1994, Discourse, Consciousness, and Time: The Flow and Displacement of Consciousness in Speaking and Writing, Chicago: The University of Chicago Press.

Chafe W., 2013, How Language Creates Beauty by Transcending Mundane Experience, Cognitive and Poetics Conference, Osnabrück, Germany, April, 2013, p. 25-27.

Fleischman S., 1990, Tense and Narrativity: From Medieval Performance to Modern Fiction, Austin: University of Texas Press.

Hopper P., 1979, Aspect and foregrounding in discourse, in: Givón T. (ed.). Discourse and Syntax. Syntax and Semantics, 12, N.Y., etc.: Academic Press, p. 213-241.

Hopper P., Thompson S., 1980, Transitivity in grammar and discourse, Language, 56, p. 251-299.

Hopper P., Thompson S. (eds.), 1982, Studies in Transitivity. Syntax and Semantics, 15, N.Y., etc.: Academic Press.

Leech G.N., 1969, A Linguistic Guide to English Poetry, London: Longman.

Manin D., 2012, The right word in the left place, Scientific Study of Literature, 2, N 2, p. 273-300.

Nofal K.H., 2011, Syntactic aspects of poetry: A pragmatic perspective, International Journal of Business and Social Science, 2, N 16, September 2011, p. 47-63.

SHEN Y., 2007, Foregrounding in poetic discourse: between deviation and cognitive constraints, Language and Literature, 16, N 2, p. 169-181. 
Talmy L., 2010, Attention phenomena, in: Geeraerts D., Cuykens H. (eds.), The Oxford Handbook of Cognitive Linguistics, Oxford: Oxford University Press, p. 264-293.

ZeLdowicz G., 2015, Об одном способе маркировать дискурсивную перспективу в лирической поэзии. Композиция и референциальные связи, или В чем не правы П. Хоппер и С. Томпсон, Linguistica Copernicana, N 12, p. 245-270.

Zeldowicz G., forthcoming, Discourse new entities and composition of lyric poem: High informativeness as foregrounding device (submitted to Journal of Pragmatics).

ЗЕльдович Г., 2015, О дискурсивной перспективе в лирической поэзии, Слова. Слова. Слова, Чикаго-Москва, N 2, с. 456-499.

Сильман Т.И., 1977, Заметки о лирике, Ленинград: Советский писатель.

Тынянов Ю.Н., 1924/1965, Проблема стихотворного языка, Москва: Советский писатель.

Яковлева Е.С., 1994, Фрагменты русской языковой картины мира (модели пространства, времени и восприятия), Москва: Гнозис.

\section{Extraverted consciousness, introverted consciousness, and the composition of lyrical discourse}

(s u m mar y)

As is well known (Chafe 1994), two types of human consciousness can be distinguished, one of which is extraverted consciousness presupposing that each event is thought of as included into relevant context, related to other 'neighboring' events, and another one is introverted consciousness, i.e. that representing events in a decontextualized, island-like manner. In the article it is shown that this distinction has immediate bearing upon composition of lyrical discourse, since its foregrounded fragments display a clear tendency towards introverted language. 